\title{
PENINGKATAN KOMPETENSI GURU DALAM MENYUSUN RPP KURIKULUM 2013 MELALUI IN HOUSE TRAINING (IHT) OLEH KEPALA SEKOLAH DI SD BUNGKUS KRETEK KABUPATEN BANTUL
}

\author{
Oleh: Suciati \\ SD Bungkus \\ Jafarsuci2@gmail.com
}

\begin{abstract}
The purpose of this study were to implemented in-house training to improve the teacher competence in organizing the leson plan of curriculum 2013 in SD Bungkus, Kretek, Bantul, at academic year of 2018/2019. This study used descriptive approach with Kimmis and Taggart design, and conducted in two cycles. The study design was conducted in the following steps: planning, action, observation, and reflection (evaluation). The data collection technique were interview, observation, and discussion. The instrument used in this study were interview sheet, leson plan document and in-house training document. The result of this study reveals there were improvement of teacher competence that determined from evaluation on completeness of the leson plan component in cycle II, compared with those in cycle I. It can be concluded from the study that in-house training may improve teacher competence in organizing the leson plan of curriculum 2013 in SD Bungkus.

Keywords: leson plan, in house training.
\end{abstract}

\section{PENDAHULUAN}

Usaha-usaha untuk mempersiapkan guru menjadi profesional telah banyak dilakukan. Kenyataan menunjukkan bahwa tidak semua guru memiliki kinerja yang baik dalam melaksanakan tugasnya. "Hal itu ditunjukkan dengan kenyataan (1) guru sering mengeluh kurikulum yang berubah-ubah, (2) guru sering mengeluhkan kurikulum yang syarat dengan beban, (3) seringnya siswa mengeluh dengan cara mengajar guru yang kurang menarik, (4) Belum menjamin kualitas pendidikan" (Imron, 2000: 5).

RPP dikembangkan oleh guru pada satuan pendidikan. Guru pada satuan pendidikan berkewajiban secara lengkap dan sistematis agar pembelajaran berlangsung secara interaktif, inspiratif, menyenangkan, menantang, memotivasi peserta didik untuk berpartisipasi aktif, serta memberikan ruang yang cukup bagi prakarsa, kreativitas, dan kemandirian sesuai bakat, minat dan perkembangan fisik serta psikologis siswa.

Masalah yang terjadi di lapangan masih banyak ditemukan adanya guru (baik di sekolah negeri maupun swasta) yang tidak bisa memperlihatkan RPP yang dibuat dengan alasan ketinggalan di rumah dan bagi guru yang sudah membuat RPP masih ditemukan adanya guru yang belum melengkapi komponen tujuan pembelajaran dan penilaian (soal, skor dan kunci jawaban), serta langkahlangkah kegiatan pembelajarannya masih dangkal. Soal, skor, dan kunci jawaban merupakan satu kesatuan yang tidak dapat dipisahkan. Pada komponen penilaian (penskoran dan kunci jawaban) sebagian besar guru tidak lengkap membuatnya dengan alasan sudah tahu dan ada di kepala. Sedangkan pada komponen tujuan pembelajaran, materi ajar, metode pembelajaran, dan sumber belajar sebagian besar guru sudah membuatnya. Masalah yang lain yaitu sebagian besar guru khususnya di sekolah swasta belum mendapatkan pelatihan pengembangan RPP.

Dengan keadaan demikian, peneliti sebagai pembina sekolah berusaha untuk mengadakan IHT dalam menyusun RPP Kurikulum 2013. RPP harus dibuat agar kegiatan pembelajaran berjalan sistematis dan mencapai tujuan pembelajaran. 
Berdasarkan latar belakang di atas, maka masalah-masalah yang muncul dapat diidentifikasikan sebagai berikut.Guru banyak yang belum paham dan termotivasi dalam menyusun RPP Kurikulum 2013 dengan lengka.Sebagian besar guru belum mendapatkan pelatihan pengembangan Kurikulum 2013.Ada guru yang tidak bisa memperlihatkan RPP Kurikulum 2013 yang dibuatnya. RPP Kurikulum 2013 yang dibuat guru komponennya belum lengkap/ tajam khususnya pada komponen langkah-langkah pembelajaran dan penilaian. Guru banyak yang mengadopsi RPP Kurikulum 2013 dari orang lain.

Berdasarkan latar belakang, identifikasi, dan pembatasan masalah di atas, diajukan rumusan masalah sebagai berikut:,Apakah melalui IHT Guru Kelas di SD Bungkus tahun pelajaran 2018/2019 dapat dapat meningkatkan kemampuan menyusun RPP Kurikulum 2013? Bagaimana langkahlangkah melalui IHT dapat meningkatkan pembuatan RPP Kurikulum 2013 bagi guru kelas di SD Bungkus Tahun Pelajaran 2018/2019?

Berdasarkan rumusan masalah diatas maka tujuan yang akan ingin dicapai dalam penelitian ini adalah :IHT dapat meningkatkan kemampuan pembuatan RPP bagi Guru Kelas di SD Bungkus tahun pelajaran 2018/2019 dapat dapat meningkatkan kemampuan menyusun RPP Kurikulum 2013. Menerapkan IHT dalam meningkatkan kemampuan penyusunan RPP Kurikulum 2013 bagi guru kelas di SD BungkusTahun Pelajarn 2018/2019.

Penelitian Tindakan Sekolah (PTS) ini diharapkan dapat memberikan Manfaat bagi guru Dapat meningkatkan kompetensi dalam membuat RPP serta menciptakan kesadaran guru tentang tanggung jawabnya terhadap pelaksanaan tugasnya.Sebagai panduan dan arahan dalam mengajar sehingga apa yang diinginkan dalam standar isi dapat tersampaikan.

\section{Rencana Pelaksanaan Pembelajaran Kurikulum 2013}

Perencanaan proses pembelajaran meliputi silabus dan RPP. Silabus merupakan sebagian sub-sistem pembelajaran yang terdiri dari atau yang satu sama yang lain saling berhubungan dalam rangka mencapai tujuan. Hal penting yang berkaitan dengan pembelajaran adalah penjabaran tujuan yang disusun berdasarkan indikator yang ditetapkan. Perencanaan program pembelajaran adalah hasil pemikiran, berupa keputusan yang akan dilaksanakan. Selanjutnya Oemar Hakim (dalam Kurniawati 2009: 74) menyatakan, bahwa perencanaan program pembelajaran pada hakekatnya merupakan perencanaan program jangka pendek untuk memperkirakan suatu proyeksi tentang sesuatu yang akan dilakukan dalam kegiatan pembelajaran".

Menurut Permendiknas No. 103 Tahun 2014, komponen RPP Kurikulum 2013 terdiri dari (a) identitas mata pelajaran, (b) kompetensi inti, (c) kompetensi dasar, (d) indikator pencapaian kompetensi, (e) materi ajar, (f) alokasi waktu, (g) kegiatan pembelajaran dengan pendekatan saintific dan tematik integratif, (h) sumber belajar, (i) penilaian hasil belajar meliputi: soal, skor dan kunci jawaban.

Permendiknas no. 103 Tahun 2014 menyatakan dalam menyusun rencana pelaksanaan pembelajaran harus memperhatikan prinsip-prinsip sebagai berikut: a) memperhatikan perbedaan individu peserta didik, b) mendorong partisipasi aktif peserta didik, c) mengembangkan budaya membaca dan menulis, d) memberikan umpan balik dan tindak lanjut, e) keterkaitan dan keterpaduan, f) menerapkan teknologi informasi dan komunikasi Rencana Pelaksanaan Pembelajaran

Langkah-langkah menyusun RPP adalah sebagai berikut: a) mengisi kolom identitas, b) Menentukan alokasi waktu yang dibutuhkan untuk pertemuan yang telah 
ditetapkan, c) Menentukan SK, KD, dan indikator yang akan digunakan yang terdapat pada silabus yang telah disusun, d) merumuskan indikator pencapaian berdasarkan KI dan KD, e) mengidentifikasi materi ajar berdasarkan materi pokok/ pembelajaran yang terdapat dalam silabus, materi ajar merupakan uraian dari materi pokok/pembelajaran, f) merumuskan langkahlangkah yang terdiri dari kegiatan awal, inti dan akhir. g) menentukan alat/bahan/sumber belajar yang digunakan, i) menyusun kriteria penilaian, lembar pengamatan, contoh soal, teknik penskoran dan kunci jawaban.

\section{In House Training (IHT)}

Dessler (1997: 263) mendefinisikan Training (pelatihan) merupakan proses mengajarkan karyawan baru atau yang sekarang, tentang keterampilan dasar yang mereka butuhkan untuk menjalankan pekerjaan mereka. Sikula mengatakan bahwa "pelatihan merupakan proses pendidikan jangka pendek yang menggunakan prosedur sistematis dan terorganisasi, yang mana tenaga nonmanajerial mempelajari pengetahuan dan keterampilan teknis untuk tujuan-tujuan tertentu".

Muhammad Saroni dalam bukunya personal branding guru mengemukakan beberapa fungsi in house training, sebagai berikut.Meningkatkan kualitas sumber daya manusia (SDM), Meningkatkan kualitas proses dan hasil, Penguasaan materi lebih baik Guru lebih kompeten dibidangnya, Pemenuhan standar kualitas guru, Meningkatnya profesionalisme guru, Banyak ilmu yang didapat untuk di implementasikan di proses pembelajara, Mendapat motivasi untuk diri sendiri dan selalu melakukan perbaikan, Selalu mengikuti perubahan pada konsep pembelajaran, Guru lebih kompeten dibidangnya.

Adapun tujuan pendidikan dan pelatihan menurut Henry Simamora dalam Ambar T. Sulistiyani \& Rosidah, (2003:174), yaitu: Memperbaiki kinerja, Memutakhirkan keahlian para pegawai sejalan dengan kemajuan teknologi, Membantu memecahkan persoalan operasional, Mengorientasikan pegawai terhadap organisasi, Memenuhi kebuthan-kebutuhan pertumbuhan pribadi, Untuk meningkatkan efisiensi dan efektivitas kerja pegawai dalam mencapai sasaran yang telah ditetapkan.

\section{Kerangka Berfikir}

Peningkatan kompetensi guru dalam pembuatan rencana pelaksanaan pembelajaran Kurikulum 2013 perlu pendampingan karena bagi guru ini merupakan hal yang baru walaupun guru telah mengikuti workshop ataupun pelatihan namun guru sangat membutuhkan pendampingan agar guru dapat melaksanakan tugas dengan baik dan juga guru mengetahui langkah langkah yang benar dalam pembuatan rencana pelaksanaan pembelajaran, dengan maksud agar guru bisa memahami dengan benar cara penyampaian pembaelajaran dengan langkah langkah sesuai dengan ketentuan yang ada pada kurikulum 2013 yaitu identitas mata pelajaran, (b) kompetensi inti, (c) kompetensi dasar, (d) indikator pencapaian kompetensi, (e) materi ajar, (f) alokasi waktu, (g) kegiatan pembelajaran dengan pendekatan saintific dan tematik integratif. (h) sumber belajar, (i) penilaian

\section{Hipotesis Tindakan}

Dari rumusan masalah yang telah ditentukan berdasarkan pada kerangka berfikir di atas, hipotesis tindakan penelitian ini adalah IHT pendampingan Kepala Sekolah dapat meningkatkan kemampuan pembuatan Rencana Pelaksanaan Pembelajaran bagi guru SD dalam implementasi Kurikulum 2013 di SD Bungkus Tahun Pelajaran 2018/2019. Paham langkah-langkah penyusunan RPP Kurikulum 2013 dengan melalui IHT oleh kepala sekolah SD Bungkus Tahun Pelajaran 2018/2019. 


\section{METODE PENELITIAN}

Lokasi penelitian di SD Bungkus, Dusun Bungkus, Desa Parangtritis, Kretek, Bantul. Subjek penelitian adalah guru-guru SD Bungkus yang terdiri dari guru kelas 1 Sampai guru Kelas VI. Kepala sekolah sebagai penelti dengan dengan ditemani kolabolator, tindakan Supervisi Klinis sedangkan guru SD Bungkus sebagai Objek sekaligus subjek. Penelitian dilakukan dari tanggal Senin 05 Maret 2018 sampai Sabtu tanggal 10 Maret 2018. Sedangkan Siklus ke II dilaksanakan pada hari Senin tanggal 12 Maret 2018 sampai Jumat 16 Maret 2018 pada semester II.

Penelitian ini dilakukan mengikuti prinsip Kimmis dan Taggart (1988) yang mencakup sebagai berikut: (1) perencanaan (planning), (2) pelaksanaan tindakan (action), (3) observasi (observation), (4) refleksi, atau evaluasi. Keempat kegiatan ini berllangsung secara berulang dalam bentuk siklus. Tahap perencanaan meliputi tindakan apa yang akan dilakukan untuk meningkatkan kompetensi guru dalam menyusun RPP secara lengkap. Solusinya yaitu dengan melakukan: a) wawancara dengan guru dengan menyiapkan lembar wawancara, b) Diskusi dalam suasana yang menyenangkan dan c) memberikan pendampingan dalam menyusun RPP Kurikulum 2013 secara lengkap. Tahap pelaksanaan meliputi apa yang dilakukan oleh peneliti sebagai upaya meningkatkan kompetensi guru dalam menyusun RPP Kurikulum 2013 yang lengkap yaitu dengan memberikan pendampingan pada guru sekolah sendiri. Pada tahap observasi peneliti melakukan pengamatan terhadap RPP Kurikulum 2013 yang telah dibuat untuk memotret seberapa jauh kemampuan guru dalam menyusun RPP Kurikulum 2013 dengan lengkap, hasil atau dampak dari tindakan yang telah dilaksanakan oleh guru dalam mencapai sasaran. Selain itu juga peneliti mencatat hal-hal yang terjadi dalam pertemuan dan wawancara. Rekaman dari pertemuan dan wawancara akan digunakan untuk analisis dan komentar kemudian. Sedangkan pada tahap refleksi peneliti mengkaji, melihat, dan mempertimbangkan hasil atau dampak dari tindakan yang telah dilakukan. Berdasarkan hasil dari refleksi ini, peneliti bersama guru melaksanakan revisi atau perbaikan terhadap RPP Kurikulum 2013 yang telah disusun agar sesuai dengan rencana awal yang mungkin saja masih bisa sesuai dengan yang peneliti inginkan.

\section{HASIL DAN PEMBAHASAN}

Berdasarkan hasil observasi peneliti terhadap enam guru tentang macam -macam penyusunan RPP dalam Kurikulum 2013 yang dibuat guru (khusus pada pratest), diperoleh informasi/data bahwa masih ada guru belum membuat. Hal ini dapat diketahui dari hasil pretest guru kelas satu sampai kelas enam, hasil observasi peneliti terhadap enam RPP Kurikulum 2013 yang dibuat guru, diperoleh informasi/data bahwa masih ada guru yang tidak melengkapi RPP-nya dengan komponen dan sub-subkomponen RPP tertentu, misalnya komponen indikator dan penilaian hasil belajar (pedoman penskoran dan kunci jawaban). Rumusan kegiatan siswa pada komponen langkah-langkah kegiatan pembelajaran masih kurang tajam, interaktif, inspiratif, menantang, dan sistematis.

Tabel 1: Rentang nilai

\begin{tabular}{cc}
\hline Peringkat & nilai \\
\hline Amat Baik $(\mathrm{AB})$ & $90<$ nilai $\leq 100$ \\
\hline Baik $(\mathrm{B})$ & $80<$ nilai $\leq 90$ \\
\hline Cukup $(\mathrm{C})$ & $70<$ nilai $\leq 80$ \\
\hline Kurang $(\mathrm{K})$ & nilai $\leq 70$ \\
\hline
\end{tabular}


Tabel 2: Target IHT penyusunan RPP

\begin{tabular}{clc}
\hline No & \multicolumn{1}{c}{ Indikator } & Target \\
\hline 1 & Mencantumkan Identitas & $100 \%$ \\
\hline 2 & Mencantumkan KI & $85 \%$ \\
\hline 3 & Mencantumkan KD & $85 \%$ \\
\hline 4 & Mencantumkan Indikator & $75 \%$ \\
\hline 5 & Mencantumkan Materi & $75 \%$ \\
\hline & $\begin{array}{l}\text { Mencantumkan Langkah- } \\
\text { langkah kegiatan } \\
\text { pembelajaran }\end{array}$ & $75 \%$ \\
\hline 7 & $\begin{array}{l}\text { Mencantumkan Alokasi } \\
\text { waktu }\end{array}$ & $70 \%$ \\
\hline 8 & $\begin{array}{l}\text { Mencantumkan Sumber } \\
\text { Belajar }\end{array}$ & $70 \%$ \\
\hline 9 & Mencantumkan Penilaian & $75 \%$ \\
\hline
\end{tabular}

\section{Siklus I, Pertemuan 1}

a) Perencanaan

Dalam perencanaan siklus I pertemuan I ini peneliti menjadwalkan 1) Guru mengisi instrumen (angket) Instrumen angket, 2) sosialisasi tujuan penelitian pada 3) Penjelasan fokus penelitian tentang IHT oleh Kepala Sekolah, 4) Selanjutnya guru kelas mengumpulkan RPP sesuai dengan kurikulum 2013, 5) Diskusi tentang penyusunan RPP yang ideal.

b) Pelaksanaan

Pada tahap ini peneliti melakukan beberapa kegiatan antara lain: 1) Peneliti mengadakan wawancara dengan guru yang akan di teliti dengan menggunakan instrumen angket yang telah tersedia 2) Pertemuan awal peneliti mengumpulkan guru SD Bungkus yaitu enam guru kelas. Dengan pengarahan dan bimbingan kepala sekolah serta melalui In House Training (IHT), guru memahami maksud dan tujuan kepala sekolah mengadakan penelitian dalam siklus I pertemuan I ini, 3) Maksud dan tujuan Penelitian Tindakan Sekolah dengan maksud untuk meningkatkan mutu pendidikan terutama Kompetensi dalam Penyusunan Rencana Pelaksanaan Pembelajaran Kurikulum 2013, 4) Penjelasan kepala sekolah In House Training (IHT) kepada guru kelas dalam penyusunan RPP dalam Implementasi Kurikulum 2013 difokuskan pada perbaikan penyusunan RPP, serta menjelaskan tentang indikator yang akan diamati melalui deskriptor setara, 5) Tanya jawab tentang segala sesuatu yang berkaitan dengan penelitian

c) Observasi

Kepala sekolah sebagai peneliti serta pendamping dan observer harus memiliki pedoman yang objektif, realitas dan dapat dipertanggung jawabkan secara moril kepada Tuhan tentang kebenaran hasil penelitian yang diperolehnya maka dari itu dalam siklus I pertemuan I ini peneliti harus bertindak1). Mengamati dan mendampingi guru-guru melalui IHT sesuai dengan rencana dengan menggunakan instrumen wawancara dan instrumen lembar 2). Hasil wawancara dari 6 guru kelas hanya 2 guru yang sudah agak paham, sedangkan yang lain belum paham (hasil pada lampiran 1), 3). Memberi penilaian pada subjek dengan menggunakan format evaluasi/ instrumen 4). Guru atau subjek yang mengumpulkan RPP kurikulum 2013 sesuai dengan indikator dan instrumen -instrumen yang telah dijelaskan sebelumnya, 5) Peneliti melakukan IHT tentang penyusunan RPP kurikulum 2013 dengan menggunakan lembar observasi yang telah disiapkan. Kepala Sekolah serta data yang diperoleh melalui wawancara, observasi dan penyebaran angket.

Tabel 3: Rekap hasil Siklus I pertemuan 1 penyusunan RPP

\begin{tabular}{rlc}
\hline No & Indikator & $\%$ \\
\hline 1 & Mencantumkan Identitas & $73 \%$ \\
\hline 2 & Mencantumkan KI & $50 \%$ \\
\hline 3 & Mencantumkan KD & $50 \%$ \\
\hline 4 & Mencantumkan Indikator & $50 \%$ \\
\hline 5 & Mencantumkan Materi & $58 \%$ \\
\hline 6 & Mencantumkan Langkah-langkah & $50 \%$ \\
\hline 7 & Mencantumkan Alokasi waktu & $54 \%$ \\
\hline 8 & Mencantumkan Sumber Belajar & $63 \%$ \\
\hline 9 & Mencantumkan Penilaian & $58 \%$ \\
\hline
\end{tabular}




\section{d. Refleksi}

Dari hasil pengamatan peneliti bersama observer maka diperoleh hasil IHT penyusunan RPP kurikulum 2013 sebagai berikut untuk guru kelas 1 dengan scor akhir 36 dengan hasil demikian dapat di kreteriakan kinerja guru tersebut cukup sehingga perlu adanya suatu tindakan yaitu diadakan siklus I pertemuan 2 untuk guru kelas II total scor akhir 42 dapat diperoleh hasil kinerja cukup sehingga perlu suatu tindakan, Demikian juga kelas III total dengan scor akhir 33 sehingga sesuai dengan kreteria yang telah ditentukan diperoleh hasil kinerja cukup perlu adanya suatu tindakan yaitu diadakan siklus I pertemuan 2, Selanjutnya untuk kelas IV sesuai dengan pengamatan diperoleh hasil total scor akhir 57 sehingga diperoleh hasil kinerja cukup dan perlu adanya suatu tindakan siklus I pertemuan 2, pada guru kelas $\mathrm{V}$ diperoleh total dengan scor akhir 60 dengan kreteria hasil kinerja cukup, untuk meningkatkan kinerja terutama dalam penyusunan RPP maka diadakan suatu tindakan siklus ke I pertemuan 2,

\section{Siklus I, Pertemuan 2}

a) Perencanaan

Kegiatan pada tahap ini meliputi: 1) sosialisasi tujuan penelitian pada guru siklus I pertemuan 2,2) penjelasan fokus penelitian IHT untuk memperbaiki siklus I pertemuan 1. Peneliti menjelaskan kepada guru jalannya IHT tentang penyusunan RPP kurikulum 2013 Pendampingan ini dilaksanakan untuk memperbaiki kegiatan-kegiatan yang belum mencapai target yang ditentukan oleh peneliti, pelaksanaan pengamatan dilaksanakan pada hari Sabtu, 29-09-2018, Peneliti dengan menggunakan instrumen yang terdiri dari 9 aspek, instrumen disediakan mengamati guru kelas dari kelas 1 sampai kelas VI, 3) Diskusi tentang pelaksanaan proses pembelajaran yang ideal. b) Pelaksanaan

Kegiatan pada tahap ini meliputi: 1) pertemuan awal peneliti mengumpulkan seluruh guru yang berjumlah 6,2 ) maksud dan tujuan Penelitian Tindakan Sekolah siklus I pertemuan 2, 3) penjelasan tentang pendampingan guru difokuskan pada perbaikan penyusunan RPP kurikulum 2013, 4) tanya jawab tentang segala sesuatu yang berkaitan dengan penelitian terutama kekurangan kekurangan pada siklus ke I

c) Observasi

Kepala sekolah sebagai peneliti atau observer harus memiliki pedoman yang objektif, realitas dan dapat dipertanggung jawabkan secara moril kepada Tuhan tentang kebenaran hasil penelitian yang diperolehnya maka dari itu peneliti harus bertindak.Dari hasil pengamatan peneliti bersama observer Pada siklus I pertemuan 2 diperoleh hasil IHT penyusunan RPP kurikulumm 2013. Belum semua guru memenuhi target yang telah ditentukan. Sehingga IHT tentang penyusunan RPP pada kurikulum 2013 dalam dianggap belum memenuhi target yang ditentukan peneliti.

Tabel 4: Rekap Hasil Siklus I Pertemuan 2 Penyusunan RPP Kurikulum 2013.

\begin{tabular}{llc}
\hline No & \multicolumn{1}{c}{ Indikator } & $\%$ \\
\hline 1. & Mencantumkan Identitas & $75 \%$ \\
\hline 2. & Mencantumkan KI & $63 \%$ \\
\hline 3. & Mencantumkan KD & $63 \%$ \\
\hline 4. & Mencantumkan Indikator & $58 \%$ \\
\hline 5. & Mencantumkan Materi & $71 \%$ \\
\hline 6. & Mencantumkan Langkah-langkah & $63 \%$ \\
\hline 7. & Mencantumkan Alokasi waktu & $58 \%$ \\
\hline 8. & Mencantumkan Sumber Belajar & $63 \%$ \\
\hline 9. & Mencantumkan Penilaian & $63 \%$ \\
\hline
\end{tabular}

d) Refleksi

Dalam grafik digambarkan bahwa dari masing-masing guru siap untuk didampingi untuk penyusunan RPP kurikulum 2013, dalam hal persiapan mengajar terbukti pada komponen setiap komponen telah diperoleh 
hasil yang baik, sehingga dalam perbaikan siklus I pertemuan 2 ini dinyatakan telah memperoleh peningkatan hasil dari pada siklus I pertemuan 1 dengan hasil yang demikian maka peneliti berdiskusi dengan observer dan peserta pendampingan untuk mengadakan siklus ke II pertemuan 1. Adapun perbandingan dari siklus I pertemuan I dengan siklus I pertemuan II adalah:
Tabel 5: Hasil Perbandingan Penyusunan RPP Siklus I Pertemuan I dan Pertemuan 2

\begin{tabular}{|c|c|}
\hline \multirow{2}{*}{ Indikator } & Siklus 1 \\
\hline & $\begin{array}{ll}\text { PT1 } & \text { PT2 }\end{array}$ \\
\hline Mencantumkan Identitas & $73 \% 75 \%$ \\
\hline$\overline{\text { Mencantumkan KI }}$ & $50 \% 63 \%$ \\
\hline Mencantumkan KD & $50 \% 63 \%$ \\
\hline$\overline{\text { Mencantumkan Indikator }}$ & $50 \% 58 \%$ \\
\hline Mencantumkan Materi & $58 \% 71 \%$ \\
\hline Mencantumkan Langkah-langkah & $50 \% 63 \%$ \\
\hline Mencantumkan Alokasi waktu & $54 \% 58 \%$ \\
\hline Mencantumkan Sumber Belajar & $63 \% 63 \%$ \\
\hline Mencantumkan Penilaian & $58 \% 63 \%$ \\
\hline
\end{tabular}

Grafik 1: Hasil Perbandingan Penyusunan RPP Siklus I Pertemuan I dan Pertemuan 2 PERBANDINGAN SIKLUS I PERTEMUAN 1 DAN PERTEMUAN 2

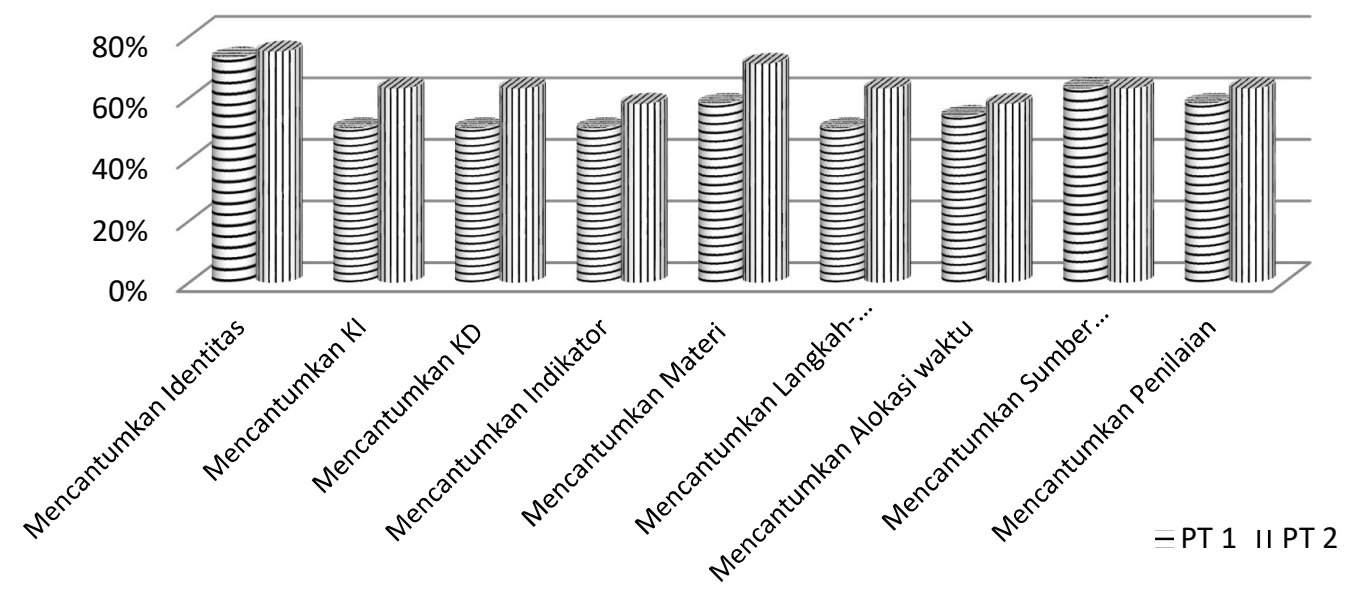

Sedangkan hasil perbandingan guru kelas yang telah diamati dalam pendampingan penyusunan RPP kurikulum 2013 pada siklus I pertemuan 1 dan pertemuan 2

\section{Siklus II, Pertemuan 1}

\section{a) Perencanaan}

Kegiatan pada tahap ini meliputi:1) sosialisasi tujuan penelitian pada guru siklus II pertemuan 1,2) penjelasan fokus penelitian dengan IHT untuk memperbaiki siklus II pertemuan 1,3) diskusi tentang pelaksanaan proses pembelajaran yang ideal.

\section{b) Pelaksanaan}

Kegiatan pada tahap ini meliputi: 1) Pertemuan awal peneliti mengumpulkan seluruh guru yang berjumlah 6,2 ) maksud dan tujuan Penelitian Tindakan Sekolah siklus II pertemuan 1,3) Penjelasan tentang pendampingan guru difokuskan pada perbaikan penyusunan RPP kurikulum 2013, serta menjelaskan tentang aspek yang akan diamati melalui deskriptor setara, 4) tanya jawab tentang segala sesuatu yang berkaitan dengan penelitian terutama kekurangan pada siklus ke I

c) Observasi

Kepala sekolah sebagai peneliti atau observer harus memiliki pedoman yang objektif, realitas dan dapat dipertanggung 
jawabkan secara moril kepada Tuhan tentang kebenaran hasil penelitian yang diperolehnya maka dari itu peneliti harus bertindak, 1) mengamati dengan menggunakan lembar observasi yang telah dibuat, 2) memberi penilaian pada subjek dengan menggunakan format evaluasi, 3) guru atau subjek yang diamati mengikuti IHT penyusunan RPP kurikulum 2013 sesuai dengan aspek dan deskriptor yang telah dijelaskan sebelumnya, 4) peneliti melakukan IHT tentang kurikulum 2013 dengan menggunakan lembar observasi yang telah disiapkan IHT data yang diperoleh.
Tabel 6: Keberhasilan Indikator Penyusunan RPP Kurikulum 2013

\begin{tabular}{lc}
\hline No & \multicolumn{1}{c}{ Indikator } \\
\hline 1. Mencantumkan Identitas & $96 \%$ \\
\hline 2. Mencantumkan KI & $79 \%$ \\
\hline 3. Mencantumkan KD & $79 \%$ \\
\hline 4. Mencantumkan Indikator & $76 \%$ \\
\hline 5. Mencantumkan Materi & $76 \%$ \\
\hline 6. Mencantumkan Langkah-langkah & $76 \%$ \\
\hline 7. Mencantumkan Alokasi waktu & $83 \%$ \\
\hline 8. Mencantumkan Sumber Belajar & $75 \%$ \\
\hline 9. Mencantumkan Penilaian & $63 \%$ \\
\hline $\begin{array}{l}\text { Jika digambarkan dengan grafik } \\
\text { berikut: }\end{array}$ &
\end{tabular}

Grafik 2: Keberhasilan Indikator Penyusunan RPP Kurikulum 2013

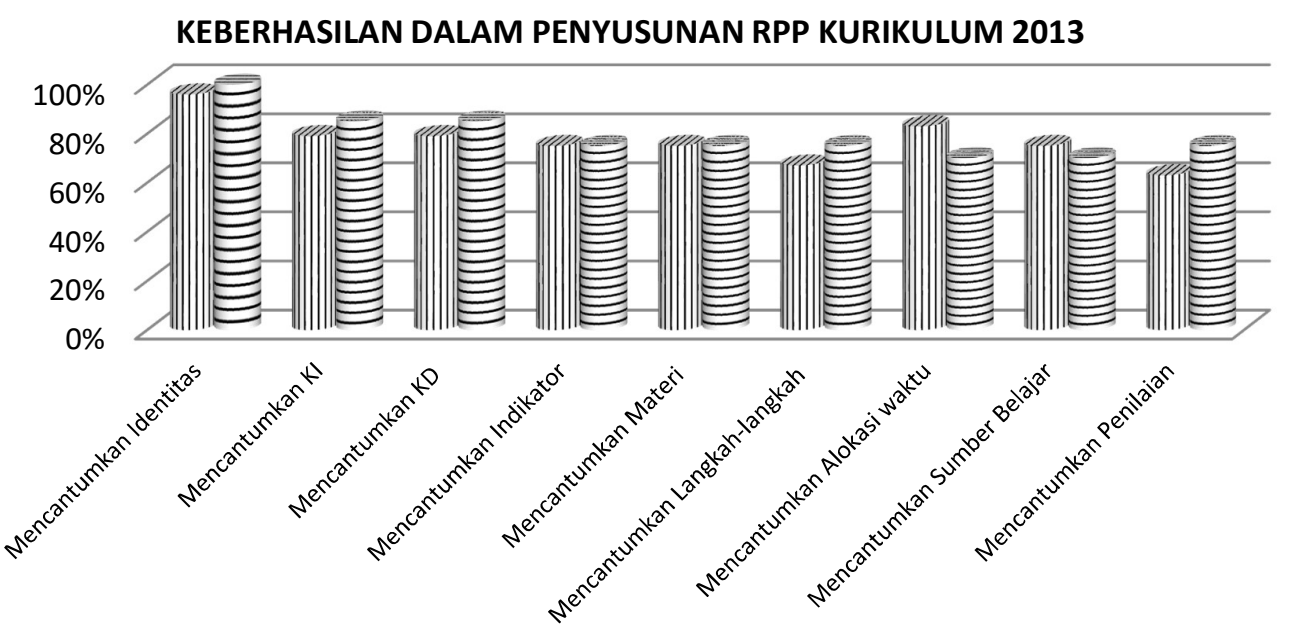

d) Refleksi

Dalam grafik digambarkan dalam perbaikan siklus II pertemuan 1 ini dinyatakan telah memperoleh peningkatan hasil dari pada siklus I pertemuan 2 hasil dengan kinerja yang baik bahkan ada yang baik sekali yaitu guru kelas VI

\section{Siklus II pertemuan 2}

a) Perencanaan

Kegiatan pada tahap ini meliputi: 1) sosialisasi tujuan penelitian pada guru siklus II pertemuan 2,2) penjelasan fokus penelitian tentang IHT untuk memperbaiki siklus II pertemuan 2. Peneliti menjelaskan kepada guru jalannya IHT tentang penyusunan RPP kurikulum 2013 Pendampingan ini, 3) diskusi

\section{PROSENTASE KEBERHASILAN =TARGET} tentang pelaksanaan proses pembelajaran yang ideal.

b) Pelaksanaan

Kegiatan pada tahap ini meliputi: 1) pertemuan awal peneliti mengumpulkan seluruh guru yang berjumlah 6,2 ) maksud dan tujuan Penelitian Tindakan Sekolah, 3) penjelasan tentang pendampingan guru difokuskan pada perbaikan penyusunan RPP kurikulum 2013, 4) Tanya jawab tentang segala sesuatu yang berkaitan dengan penelitian terutama kekurangan kekurangan pada siklus ke II.

c) Observasi

Kegiatan pada tahap ini meliputi: 1). Mengamati sesuai dengan rencana dengan 
menggunakan lembar observasi yang telah dibuat, 2) memberi penilaian pada subjek dengan menggunakan format evaluasi, 3) guru atau subjek yang diamati mengikuti pendampingan melalui IHT penyusunan RPP kurikulum 2013 sesuai dengan aspek dan deskriptor yang telah dijelaskan sebelumnya, 4) peneliti melakukan pendampingan dengan IHT tentang kurikulum 2013 dengan menggunakan lembar observasi yang telah disiapkan.

Tabel 7: Keberhasilan indikator RPP

\begin{tabular}{lccc}
\hline \multicolumn{1}{c}{ Indikator } & Prosentase keberhasilan & Prosentas target & Target \\
\hline Mencantumkan Identitas & $96 \%$ & $100 \%$ & Belum tercapai \\
\hline Mencantumkan KI & $87 \%$ & $85 \%$ & Belum tercapai \\
\hline Mencantumkan KD & $87 \%$ & $85 \%$ & Belum tercapai \\
\hline Mencantumkan Indikator & $83 \%$ & $75 \%$ & Sudah tercapai \\
\hline Mencantumkan Materi & $87 \%$ & $75 \%$ & Belum tercapai \\
\hline Mencantumkan Langkah-langkah & $79 \%$ & $75 \%$ & Belum tercapai \\
\hline Mencantumkan Alokasi waktu & $83 \%$ & $70 \%$ & Sudah tercapai \\
\hline Mencantumkan Sumber Belajar & $91 \%$ & $70 \%$ & Sudah tercapai \\
\hline Mencantumkan Penilaian & $88 \%$ & $75 \%$ & Belum tercapai \\
\hline
\end{tabular}

Grafik 3: Keberhasilan indikat PP

HASIL INDIKATOR PENYUSUNAN RPP KURIKULUM 2013

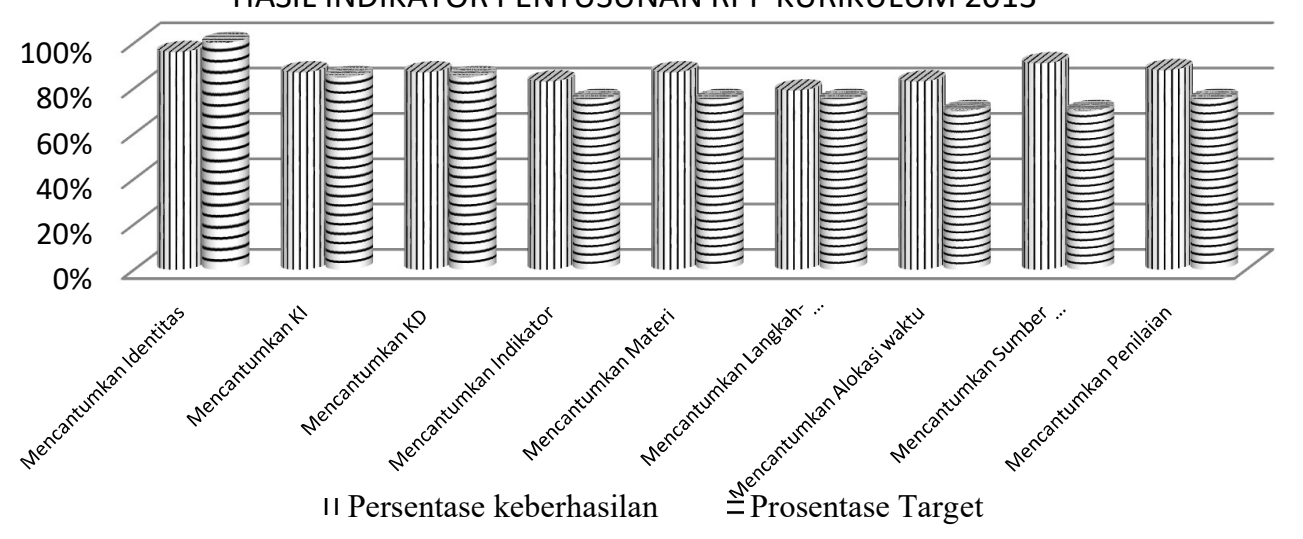

d) Refleksi

Dari pengamatan yang telah dilakukan peneliti bahwa dari masing-masing guru siap untuk penyusunan RPP kurikulum 2013 dengan susunan yang baik dan benar menurut kaidah yang telah ditentukan, dalam instrumen penyususnan RPP yang paling sulit pada aspek langkah langkah dan penilaian terbukti pada indikator ini setiap guru kelas memperoleh hasil yang pada awalnya kurang baik, sehingga dalam perbaikan siklus II ini dinyatakan telah memperoleh peningkatan hasil dengan kinerja baik bahkan ada yang baik sekali yaitu guru kelas V dan kelas VI dengan scor hasil 94 dan 97 adapun refleksi dari masing masing kelas adalah sebagai berikut:

Tabel 8: Hasil Perbandingan Penyusunan RPP Siklus II Pertemuan I dan Pertemuan 2

\begin{tabular}{lcc}
\hline \multirow{2}{*}{ Indikator } & \multicolumn{2}{c}{ Siklus 2} \\
\cline { 2 - 3 } & PT1 & PT2 \\
\hline Mencantumkan Identitas & $96 \%$ & $96 \%$ \\
\hline Mencantumkan KI & $79 \%$ & $87 \%$ \\
\hline Mencantumkan KD & $79 \%$ & $87 \%$ \\
\hline Mencantumkan Indikator & $76 \%$ & $83 \%$ \\
\hline Mencantumkan Materi & $76 \%$ & $87 \%$ \\
\hline Mencantumkan Langkah-langkah & $76 \%$ & $79 \%$ \\
\hline Mencantumkan Alokasi waktu & $83 \%$ & $83 \%$ \\
\hline Mencantumkan Sumber Belajar & $76 \%$ & $91 \%$ \\
\hline Mencantumkan Penilaian & $76 \%$ & $88 \%$ \\
\hline
\end{tabular}


Grafik 4: Hasil Perbandingan Penyusunan RPP Siklus II Pertemuan I dan Pertemuan 2

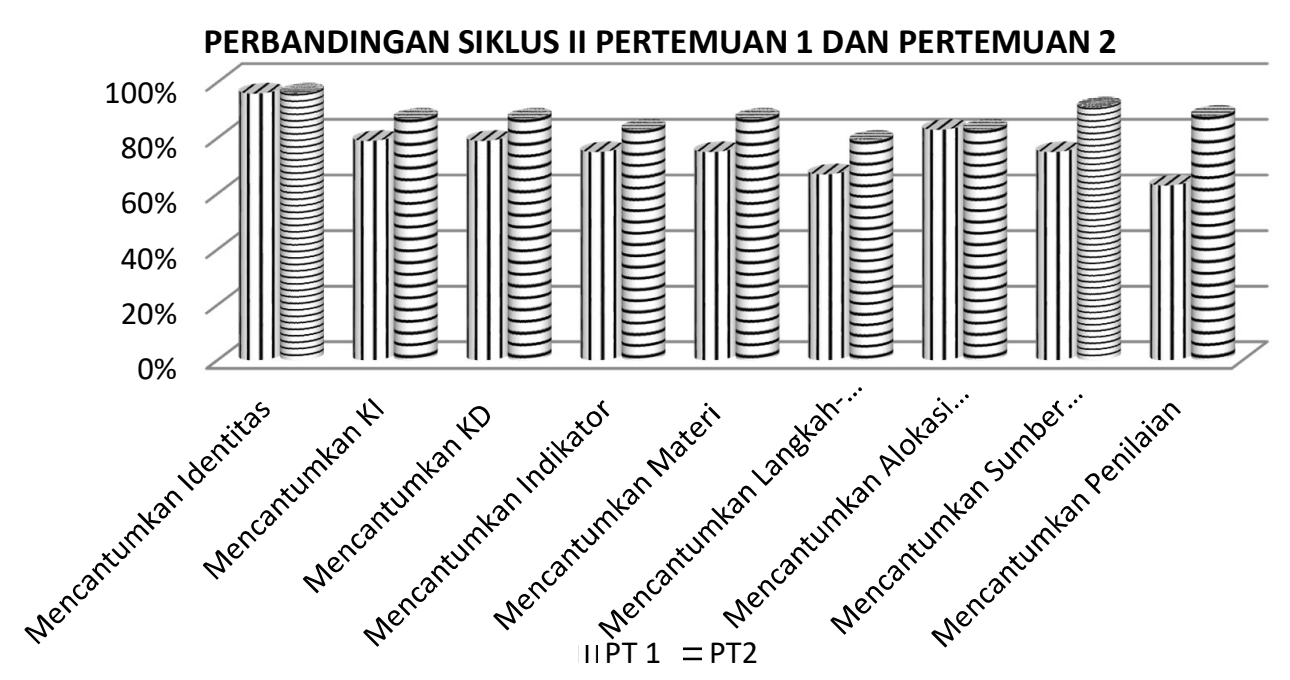

\section{PEMBAHASAN}

Dari hasil pengamatan dan penelitian yang dilakukan oleh peneliti dari instrumen melalui IHT dalam Penyusunan RPP Kurikulum 2018 yang terdiri dari 9 Indikator kegiatan dalam pendampingan dengan IHT dalam penyusunan RPP kurikulum 2013 yang terdiri dari 9 indikator terdiri dari mencantumkan Identitas, mencantumkan KI, Mencantumkan $\mathrm{KD}$, mencantumkan Indikator, mencantumkan materi, mencantumkan langkah-langkah, mencantumkan Alokasi Waktu, Mencantumkan Sumber Belajar, dan mencantumkan Penilaian, sedangkan pada masing masing indikator terdiri dari berbagai aspek yang jumlahnya adabeberapa aspek diantaranya indikator pada mencantumkan identitas terdiri dari 2 aspek yaitu:identitas ditulis dengan huruf yang tepat, dan ditulis dengan tulisan yang benar. Sedangkan pada mencantumkan KI terdiri dari 2 aspek yang dinilai yaitu urutan sesuai urutan, sesuai kaidah. mencantumkan KD yang terdiri dari mengacu pada KI dan sesuai dengan ketentuan KI, Mencantumkan Indikator yang terdiri dari 3 aspek menggunakan katakata operasional, sesuai dengan karakteristik anak, dan dirumuskan dengan kata kata yang dapat diobservasi, mencantumkan materi terdiri dari aspek sesuai denganindikatornya, sesuai dengan KI, mencantumkan langkah langkah aspek yang dinilai Apersepsi, Kegiatan Belajar Menngajar, dan penutup, mencantumkan alokasi waktu aspek yang dinilai sesuai dengan ketentuan, sesuai urutan penyusunan RPP, Mencantumkan sumber belajar aspek yang dinilai adalah sesuai dengan materi, sesuai dengan KD, Jika kita lihat tabel diatas IHT Pada penyusunan RPP kurikulum 2013 pada siklus I dan siklus II mencapai yang ditentukan oleh peneliti yaitu $75 \%$ dengan hasil kinerja rata rata guru SD Bungkus baik bahkan ada 2 guru sangat baik, sehingga dapat dikatakan IHT telah berhasil denagn baik sesuai dengan pendapat." Chiskon 1959 (dalam RM Fatihah http://eko13.wordpress. com) menyatakan, IHT "membantu individu untuk lebih mengenal berbagai informasi tentang dirinya sendiri" 
Tabel 9: Hasil Pengamatan Penyusunan RPP Kurikulum 2013

\begin{tabular}{lcccccc}
\hline \multirow{2}{*}{\multicolumn{1}{c}{ Indikator }} & Keadaan & \multicolumn{2}{c}{ Siklus I } & \multicolumn{2}{c}{ Siklus II } & \multirow{2}{*}{ awal } \\
\cline { 3 - 6 } & PT 1 & PT 2 & PT1 & PT2 & \\
\hline Mencantumkan Identitas & $60 \%$ & $73 \%$ & $75 \%$ & $96 \%$ & $96 \%$ & Tercapai \\
\hline Mencantumkan KI & $40 \%$ & $50 \%$ & $63 \%$ & $79 \%$ & $87 \%$ & Tercapai \\
\hline Mencantumkan KD & $45 \%$ & $50 \%$ & $63 \%$ & $79 \%$ & $87 \%$ & Tercapai \\
\hline Mencantumkan Indikator & $30 \%$ & $50 \%$ & $58 \%$ & $75 \%$ & $83 \%$ & Tercapai \\
\hline Mencantumkan Materi & $40 \%$ & $58 \%$ & $71 \%$ & $75 \%$ & $87 \%$ & Tercapai \\
\hline $\begin{array}{l}\text { Mencantumkan Langkah-langkah } \\
\text { kegiatan pembelajaran }\end{array}$ & $25 \%$ & $50 \%$ & $63 \%$ & $67 \%$ & $79 \%$ & Tercapai \\
\hline Mencantumkan Alokasi waktu & $40 \%$ & $54 \%$ & $58 \%$ & $83 \%$ & $83 \%$ & Tercapai \\
\hline Mencantumkan Sumber Belajar & $30 \%$ & $63 \%$ & $63 \%$ & $75 \%$ & $91 \%$ & Tercapai \\
\hline Mencantumkan Penilaian & $25 \%$ & $58 \%$ & $63 \%$ & $63 \%$ & $88 \%$ & Ter capai \\
\hline
\end{tabular}

Adapun dari tabel diatas pada siklus II mendapatkan hasil prosentase yang meningkat dan mencapai hasil seperti apa yang di targetkan.

Grafik 5: Hasil Pengamatan Penyusunan RPP Kurikulum 2013 Pengetahuan awal dan Siklus 1 dan II

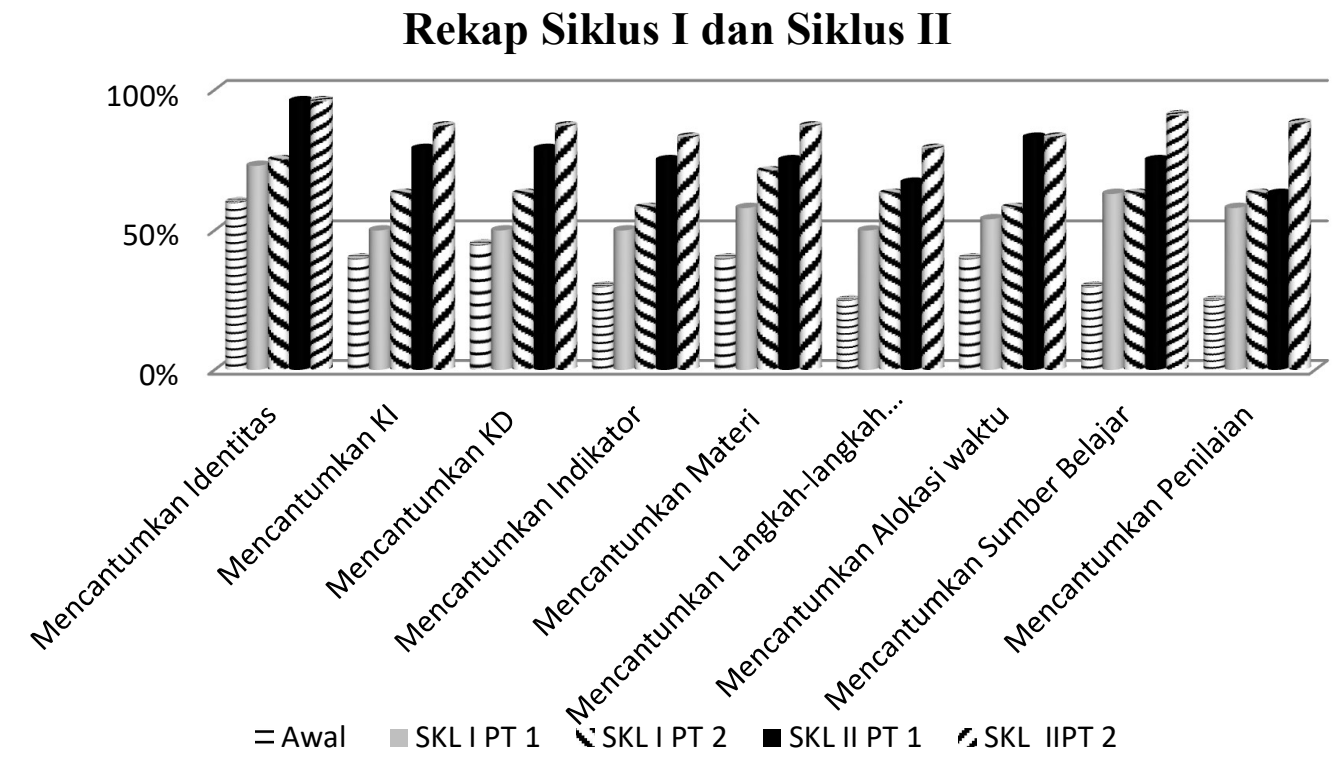

\section{KESIMPULAN}

Berdasarkan hasil Penelitian Tindakan

Sekolah (PTS) dapat disimpulkan sebagai berikut. 1) IHT dapat meningkatkan motivasi guru dalam menyusun RPP Kurikulum 2013 dengan lengkap. Guru menunjukkan keseriusan dalam memahami dan menyusun RPP Kurikulum 2013 apalagi setelah mendapatkan bimbingan pengembangan/ penyusunan RPP dari peneliti. Informasi ini peneliti peroleh dari hasil pengamatan pada pendampingan dengan IHT dalam pengembangan/penyusunan RPP Kurikulum 2013 kepada para guru, 2) Langkah-langkah IHT dapat meningkatkan penyusunan Rencana pelaksanaan pembelajaran bagi guru untuk mengimplementasikan Kurikulum 2013 di SD Bungkus Tahun Pelajaran 2018/2019, 3) Langkah-langkah IHT dapat meningkatkan kompetensi guru dalam menyusun RPP Kurikulum 2013. Hal itu dapat dibuktikan dari hasil observasi/ pengamatan yang memperlihatkan bahwa terjadi peningkatan 
kompetensi guru dalam menyusun RPP Kurikulum 2013 dari siklus ke siklus.

Motivasi yang sudah tertanam khususnya dalam penyusunan RPP Kurikulum 2013 hendaknya terus dipertahankan dan ditingkatkan/ dikembangkan. RPP Kurikulum 2013 yang disusun/dibuat hendaknya mengandung komponen-komponen RPP secara lengkap dan baik karena RPP Kurikulum 2013 merupakan acuan/pedoman dalam melaksanakan pembelajaran. Dokumen RPP Kurikulum 2013 hendaknya dibuat minimal dua rangkap, satu untuk arsip sekolah dan satunya lagi untuk pegangan guru dalam melaksanakan proses pembelajaran.

\section{DAFTAR PUSTAKA}

Daradjat, Zakiyah. 1980. Kepribadian Guru. Jakarta: Bulan Bintang.

Dewi, Kurniawati E. 2009. Pengembangan Bahan Ajar Bahasa Dan Sastra Indonesia dengan Pendekatan Tematis. Tesis. Surakarta: Program Pascasarjana Universitas Sebelas Maret.

Depdiknas. 2003. UU RI No. 20 Tahun 2003 tentang Sistem Pendidikan Nasional. Jakarta.

Depdiknas. 2004. Standar Kompetensi Guru Sekolah Dasar. Jakarta.

Depdiknas. 2005. UU RI No. 14 Tahun 2005 tentang Guru dan Dosen. Jakarta

Depdiknas. 2005. Standar Nasional Pendidikan. Jakarta
Depdiknas. 2007. Permendiknas RI No. 41 Tahun 2007 a tentang Standar Proses. Jakarta

Depdiknas. 2007. Permendiknas RI No. 12 Tahun 2007b tentang Standar Pengawas Sekolah/Madrasah. Jakarata

Depdiknas. 2008. Perangkat Pembelajaran Kurikulum Tingkat Satuan Pembelajaran SMA. Jakarta. 2008. Alat Penilaian Kemampuan Guru. Jakarta

Depdiknas. 2009. Petunjuk Teknis Pembuatan Laporan Penelitian Tindakan Sekolah Sebagai Karya Tulis Ilmiah Dalam Kegiatan Pengembangan Profesi Pengawas Sekolah. Jakarta.

Fatihah, RM . 2008. Pengertian konseling. http://eko13.wordpress.com, diakses 19 Maret 2009.

Kemendiknas. 2015. Penelitian Tindakan Sekolah. Jakarta.

Kemendiknas. 2015. Supervisi Akademik. Jakarta.

Kumaidi. 2008. Sistem Sertifikasi. http://massofa.wordpress.com diakses 10 Agustus 2009.

Nawawi, Hadari. 1985. Metode Penelitian Bidang Sosial. Yogyakarta: Gadjah Mada University Press.

Nurhadi. 2004. Kurikulum 2004. Jakarta: PT Gramedia Widiasarana Indonesia.

Pidarta, Made. 1992. Pemikiran Tentang Supervisi Pendidikan. Jakarta: Bumi Aksara. 